\title{
Onde mora a culpa \\ A residência e o fluxo dos perseguidos na segunda visitação do Santo Ofício à Bahia (1618)
}

\author{
Where does the guilt live \\ The residence and circulation of the persecuted during the \\ second visit of the Santo Ofício to Bahia (1618) \\ Jéssika de Souza Cabral ${ }^{*}$ \\ https://orcid.org/0000-0002-3377-9343
}

\begin{abstract}
Resumo
O objetivo deste trabalho é apresentar a cidade de Salvador (1618) por meio das descrições dos seus moradores, encontradas nos depoimentos feitos ao visitador licenciado Marcos Teixeira. Nos registros do tribunal lisboeta foram colhidas as referências espaciais de residência e circulação dos envolvidos nos delitos da fé. Assim, o roteiro de apresentação da cidade segue o movimento das histórias dos confitentes e denunciantes. Tentamos aqui inserir o espaço no tempo, aspecto pouco explorado na documentação inquisitorial. Para essa tarefa foram utilizados cronistas como Gabriel Soares de Souza e o Padre Fernão Cardim, além de mapas históricos de cartógrafos como João Teixeira Albernaz I e Hassel Gerritsz.
\end{abstract}

Palavras-chave: Espaço colonial; História colonial; Bahia; Cartografia social; Visitação Inquisitorial.

\begin{abstract}
The objective of this work is to present the city of Salvador (1618) through the descriptions of its residents, found in the statements made to the licensed visitor Marcos Teixeira. In the records of the Lisbon court, spatial references of residence and circulation of those involved in the crimes of faith were collected. Thus, the city's presentation itinerary follows the movement of the stories of confitentes and whistleblowers. We try here to insert space in time, an aspect little explored in the inquisitorial documentation. Chroniclers like Gabriel Soares de Souza and Padre Fernão Cardim were used for this task, in addition to historical maps by cartographers like João Teixeira Albernaz I and Hassel Gerritsz.
\end{abstract}

Keywords: Colonial space; Colonial history; Bahia; Social cartography; Inquisitorial Visitation.

\footnotetext{
* Doutoranda em História pelo Programa de Pós-Graduação em História (PPHR) da Universidade Federal Rural do Rio de Janeiro - UFRRJ. E-mail: jessikacabral@ufrrj.br
} 


\section{Introdução}

A ideia desse artigo surgiu durante a leitura do livro "Domingos Sodré um sacerdote africano: Escravidão, liberdade e candomblé na Bahia do século XIX", que aborda distintos momentos na vida do personagem escravo a chefe da junta de alforria na Bahia. O autor emprega como metodologia a circularidade cultural, que consiste na busca por informações do biografado em fragmentos da vida de outros atores sociais, recorrendo a fontes diversificadas. Durante a narrativa são descritas ruas, elementos urbanos, construções religiosas e a residência de Sodré. As páginas formam, imediatamente, um roteiro da cidade de Salvador nos tempos do babalaô. ${ }^{1}$

A riqueza de detalhes da cidade nos remeteu à documentação inquisitorial, que também apresenta referências espaciais semelhantes, por vezes subjetivas. Trata-se das relações de causa da segunda Visitação às partes da Bahia em 1618, encabeçada pelo inquisidor licenciado Marcos Teixeira. ${ }^{2} \mathrm{Da}$ leitura dos relatos surgiu a ideia de criar visualizações da cidade de Salvador com base nos depoimentos dos envolvidos.

A cartografia social não é uma tarefa fácil. As localidades mencionadas nas fontes nem sempre podem ser encontradas, pois os topônimos não possuem correspondência com os atuais. Para georreferenciá-las foi necessário recorrer a fontes visuais e escritas. Tal exercício também poderia ser chamado de confrontação dos dados, pois as visualizações foram feitas com base nas descrições de cronistas, nos mapas e nos registros inquisitoriais. Utilizamos os relatos de Gabriel Soares de Souza e do padre Fernão Cardim, contemporâneos, que escrevem sobre a cidade e o seu entorno em fins do século XVI. Também lançamos mão de quatro mapas históricos de períodos diferentes para cruzar as informações das legendas escritas pelos cartógrafos.

\footnotetext{
${ }^{1}$ REIS, João José. Domingos Sodré, um sacerdote africano: escravidão, liberdade e candomblé na Bahia do século XIX (São Paulo, SP: Companhia das Letras, 2008).

${ }^{2}$ A documentação de todas as visitações está disponível no Arquivo Nacional Torre do Tombo. o livro das denunciações que se fizeram em 1618 se encontra transcrito na colecção "Manuscritos do Brasil", n. . 17. V. "Segunda Visitação do Santo Ofício às Partes do Brasil", "Denunciações da Bahia", in "Anais da Biblioteca Nacional do Rio de Janeiro", vol. XLIX, ano 1927 (publicado em 1936). Os dados foram coletados e organizados em um banco de dados próprio, contendo 169 registros entre confissões e denunciações, divididos entre os campos de: nome, naturalidade, residência, idade, ocupação, condição, nome do senhor (no caso de escravos) e observações gerais.
} 
A respeito dos mapas, os dois primeiros são da autoria de João Teixeira Albernaz ${ }^{3}$ e estão reproduzidos no Livro que dá razão (ou rezão) do Estado do Brasil, de 1612. João Teixeira Albernaz I, herdeiro de uma tradição, era filho de um dos grandes cartógrafos da coroa portuguesa no século XVI. ${ }^{4} \mathrm{O}$ terceiro foi elaborado pelo cartógrafo oficial da Companhia Holandesa das índias Ocidentais (WIC), Hessel Gerritsz, já reconhecido como tal neste momento da sua vida (1625-1628), quando embarcou com a companhia com objetivo de retratar não apenas o Brasil, mas toda a costa Americana. ${ }^{5}$ O quarto foi construído por Frans Hogenberg para a coletânea Civitates Orbis Terrarum, organizada em seis volumes, entre os anos de 1540-1622, disponível na Library of Congress Geography and Map Division Washington.

Mapa 1: Planta da cidade de Salvador de João Teixeira Albernaz

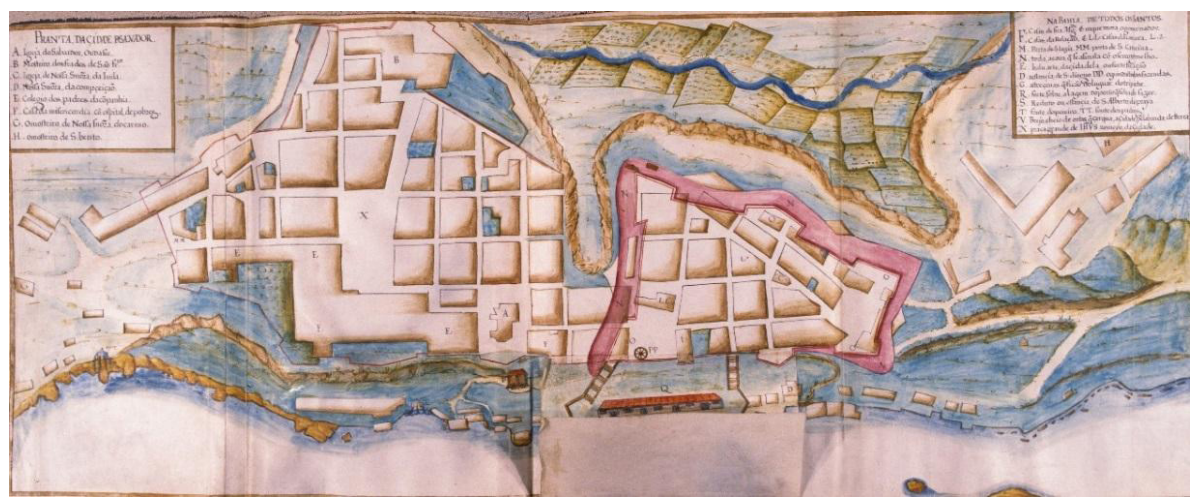

Fonte: Autoria atribuída a Diogo de Campos Moreno. Mapas de João Teixeira Albernaz I. Manuscrito Livro que dá razão (ou rezão) do Estado do Brasil. (p.122-150). Arquivo digital da Biblioteca pública municipal do Porto.

\footnotetext{
${ }^{3}$ A relação de todos os mapas de Albernaz no Livro que dá razão (ou rezão) do Estado do Brasil: PEREIRA, Levy. “(Albernaz, 1616)”. In: BiblioAtlas - Biblioteca de Referências do Atlas Digital da América Lusa. Disponível em: http://lhs.unb.br/atlas/(Albernaz,_1616).

${ }^{4}$ Há evidências de que a produção de Albernaz se concentrou entre os anos: 1626-1631 e 1640-1642. Ver em: MENEZES, Paulo Márcio Leal. «Atlas Praguense de João Teixeira Albernaz I - comparações comentadas de alguns de seus mapas", CARTOGRAFIA HISTÓRICA - TOMO II, Museu de História Natural e Jardim Botânico Universidade Federal de Minas Gerais, v. 20 n. 2 (2011).

${ }^{5}$ G. SCHILDER, The Netherland Nautical Cartography from 1550 to 1650, Centro de Estudos de História e de Cartografia Antiga Lisboa: Série separatas (Instituto de Investigação Científica Tropical, 1984). p.111-112
} 
Mapa 2: Cópia da planta de Albernaz

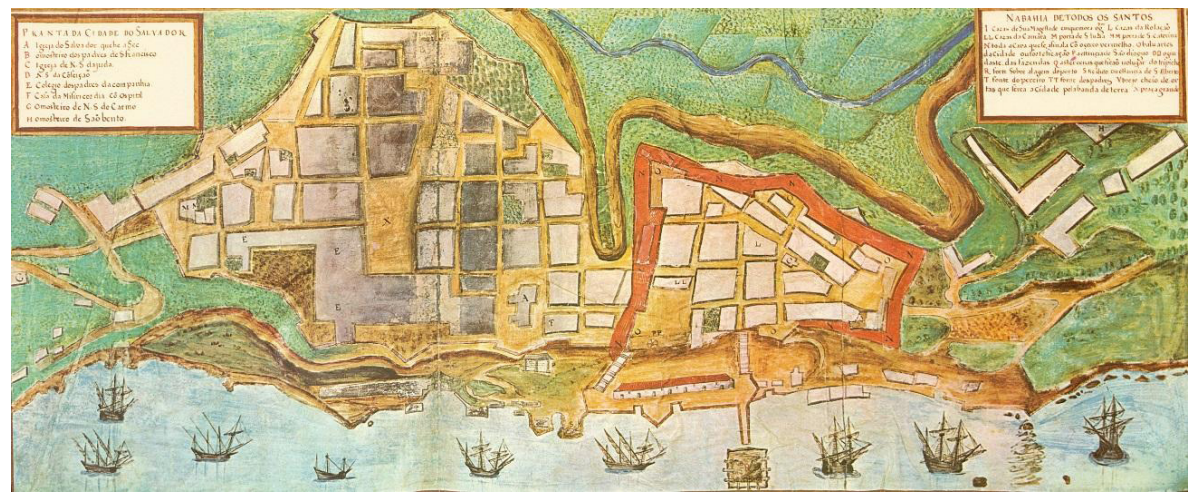

Fonte: Fernando Machado Leal. Catedral Basílica de São Salvador da Bahia: 1657. Cathedral Basilica of São Salvador da Bahia, 2a ed. (Salvador: IPAC, Instituto do Patrimônio Artístico e Cultural da Bahia, 2002).

\section{Mapa 3: Hassel Gerritsz}

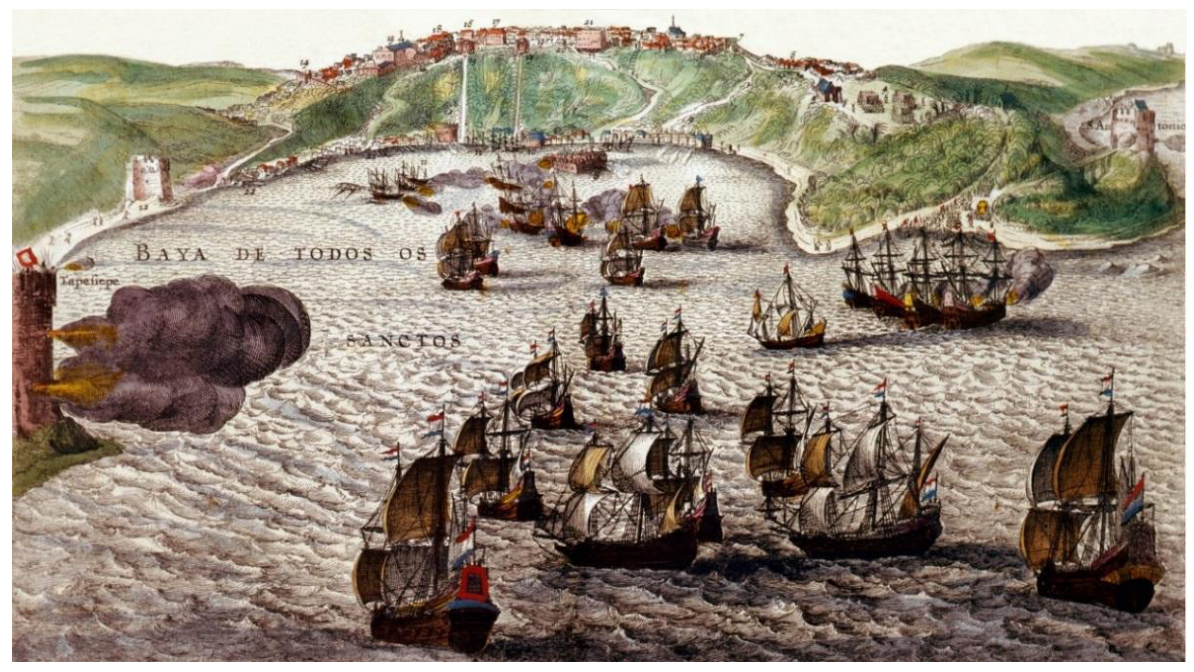

Fonte: Joannes de Laet. Beschrijvinghe van West-Indien. Bij de Elzeviers, Tot Leyden. p. 501-552. 


\section{Mapa 4: Frans Hogenberg}

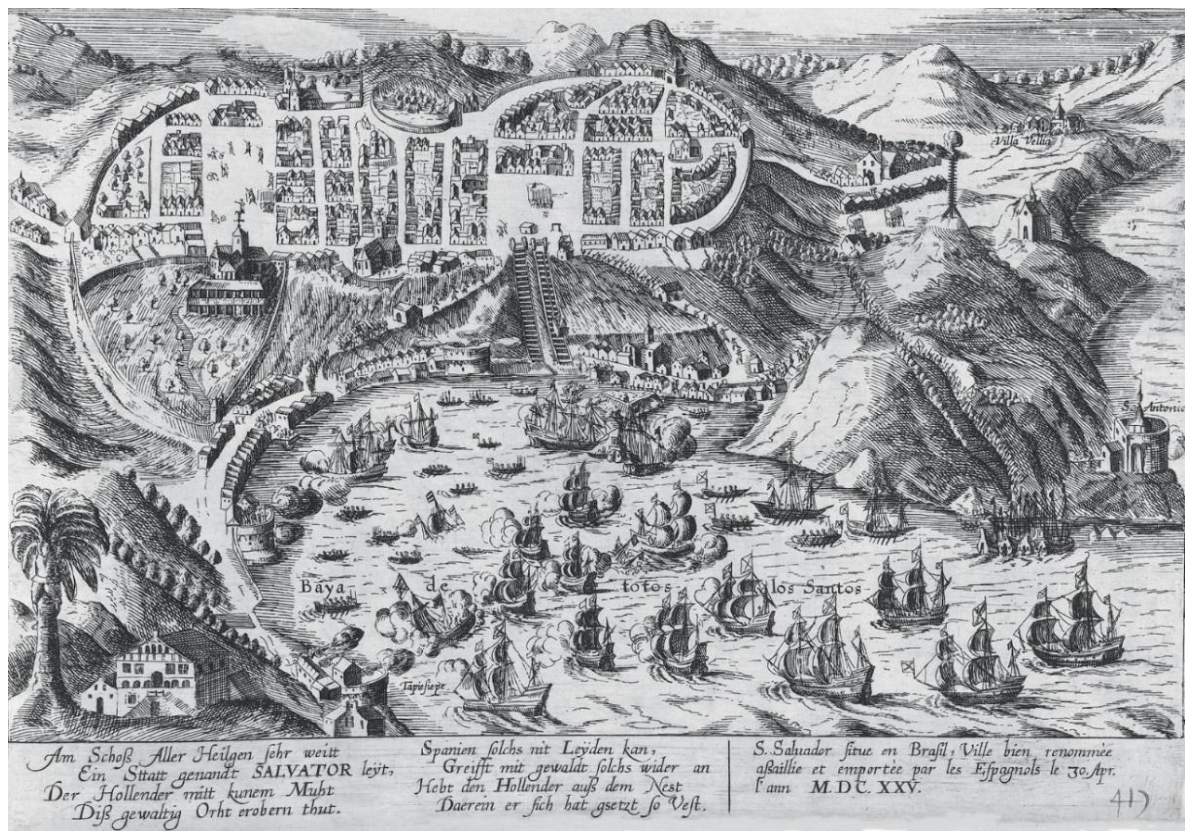

Fonte: Georg Braun. Civitates orbis terrarum. Civitates orbis terrarvm. 1541-1622 [Coloniae Agrippinae : apud Petrum à Brachel, sumptibus auctorum, 1612-1618] Not drawn to scale. 1 atlas (6 v. in 3): hand col. ill., hand col. maps (some folded); $43 \mathrm{~cm}$. G1028.B7 1612.

Pelos mapas aludidos, pode-se constatar aspectos importantes relativos às suas confecções:

1) Muitas vezes o cartógrafo enumera um dado elemento urbano (um poço, uma fortificação, uma prisão etc.), mas não o insere na legenda; daí a necessidade de comparar com outros mapas para aferir de que prédio se tratava. Isso nos obrigou a observar que elementos estavam presentes em um mapa, mas não necessariamente em outros, e assim sucessivamente.

2) Nas fontes inquisitoriais, há alusões textuais a dada toponímia ou edificação não localizadas nos mapas. Por exemplo, o escrivão licenciado do tribunal registrou que o soldado João Fernandez morava "na rua atrás da prisão", mas a prisão não se encontra representada na planta nem na legenda dos mapas (Mapas 1 e 2). A primeira hipótese que poderia explicar tal esquecimento do cartógrafo seria a inexistência do presídio durante o desenho da planta, pois há uma diferença de dois anos entre a sua elaboração 
e o depoimento do soldado. A segunda é que o presídio poderia ter mudado de lugar. Apesar de todas as ressalvas, o prédio pode ser visto no mapa de Frans Hogenberg (Mapa 4).

3) Em outros casos, o elemento aparece na legenda, mas não na planta, levando-nos mais uma vez a consultar outras fontes. A "Porta de Santa Luzia" que tinha por código "MM", como mostra a legenda dos mapas 1 e 2 , não foi representada em nenhuma das plantas de Albernaz. ${ }^{6}$ De acordo com os registros da visitação essa porta se localizava do lado sul, depois da "rua direita". Para encontrar a porta foi necessário antes localizar a "rua direita".

O seguinte passo foi buscar essa referência na descrição da toponímia realizada por Gabriel Soares Souza em seu Tratado Descriptivo do Brasil, escrito em 1587 e publicado em 1851, quando menciona a cidade pela "banda sul"7 e cita uma rua muito povoada que nos fez acreditar que pudesse ser a famosa "rua direita". Nesse caso, também havia a proximidade com a "Hermida de Nossa de Santa Luzia" e com a "Igreja de Nossa Senhora da Ajuda", antiga Sé, e nisso concordam tanto Gabriel Souza e o padre Fernão Cardim. ${ }^{8}$ Tudo indica que a antiga Porta de Santa Luzia está localizada na atual praça Castro Alves. ${ }^{9}$

4) Provavelmente, por se tratarem de plantas, alguns elementos representados ainda não haviam sido construídos. O símbolo "R", presente nas legendas dos mapas 1 e 2, corresponderia ao "forte sobre a lagem do porto que se há de fazer", no entanto só foi descrito graficamente no mapa 2. Por que isso aconteceria?

Albernaz tentou retratar em um único mapa dois tempos distintos, presente e futuro (Mapas 5 e 6), através de uma dobra no papel. No papel dobrado os prédios existentes, no papel aberto os que ainda seriam construídos. A dobra revela, talvez, como Salvador era vista cartograficamente e o que desejava que viesse a ser. Há indícios de que o mapa 2 tenha sido elaborado a partir do mapa 6, copiando todos os elementos com a folha aberta, dando assim a impressão de que o tal forte existia.

A projeção de um prédio que não havia saído do papel indica a exaltação dos tributos da cidade, ressaltando a importância política e econômica expressa em suas construções, nos prédios religiosos e públicos, no aumento populacional sugerido fontes de água, além da necessidade de proteção referida em baluartes e na promessa de um forte.

\footnotetext{
${ }^{6} \mathrm{O}$ mesmo acontece com o elemento "L2" que está na legenda, mas não na planta.

${ }^{7}$ SOUZA, Gabriel Soares. Tratado descriptivo do Brasil em 1587, 2 ed. (Rio de Janeiro: Typographia de João Ignacio da Silva, 1879), Cap XI, pág. 122-123.

${ }^{8}$ CARDIM, Fernão. Narrativa epistolar de uma viagem e missão jesuitica..., acesso: 5 de maio de 2020.

${ }^{9}$ Chegamos a essa informação com o uso da ferramenta google Earth.
} 
Mapa 5: A planta da cidade de Salvador e a dobra do papel

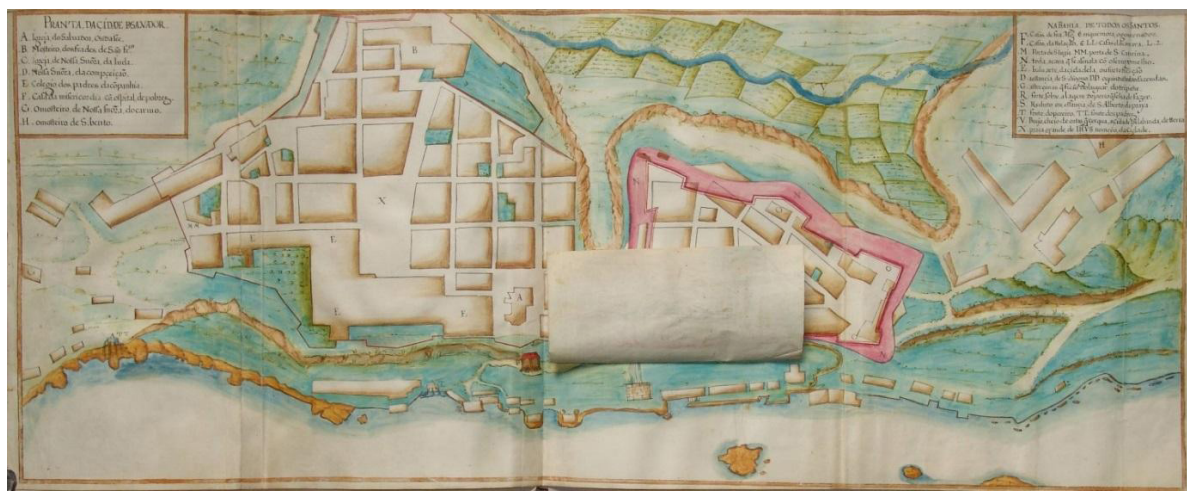

Fonte: Autoria atribuída a Diogo de Campos Moreno. Mapas de João Teixeira Albernaz I. Manuscrito Livro que dá razão (ou rezão) do Estado do Brasil. (p.122-150). Arquivo digital da Biblioteca pública municipal do Porto.

Mapa 6: A planta da cidade de Salvador sem a dobra do papel

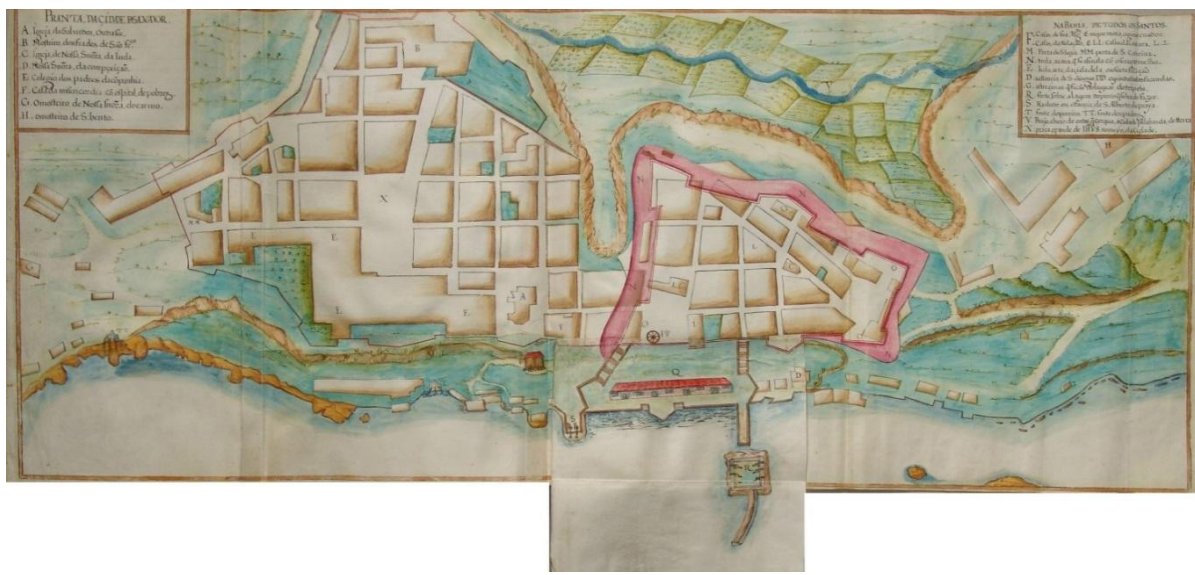

Fonte: Autoria atribuída a Diogo de Campos Moreno. Mapas de João Teixeira Albernaz I. Manuscrito Livro que dá razão (ou rezão) do Estado do Brasil. (p.122-150). Arquivo digital da Biblioteca pública municipal do Porto.

Além do exposto, as alusões toponímicas contidas nas confissões e denunciações também não são claras para o nosso tempo, a exemplo de: "morador na estrada que vai para a fonte do Pereiro", "na rua atrás do colégio" ou "abaixo do Mosteiro de São Bento desta cidade". Em certas situações aferimos 
informações complementares a respeito do endereço de um dado cristão através dos depoimentos de outros. É o caso da "rua direita", cujos indícios para localizá-la vieram das confissões de Duarte Ribeiro que disse viver na "rua direita indo para as Portas de Santa Luzia" e de Belchior Fernandes de Basto, residente na "Rua Direita além da praça pequena".

Provavelmente o escrivão licenciado se orientou pela própria localização, tomando como ponto de partida o Colégio dos Padres da Companhia (Mapa 7), lugar onde a Visitação foi conduzida.

Na descrição de Gabriel Soares de Souza havia nessas partes uma praça central cercada por elementos urbanos tais como a câmara, a cadeia, os armazéns da alfândega, as casas de negócios e a casa do governador, e adiante duas ruas principais bem povoadas de lojas de mercadores. ${ }^{10}$ Acreditamos que se tratava da "rua direita" e dos "mercadores". Os registros do Tribunal reforçam tal suposição, pois, dos cinco processados que deram a "Rua Direita" como paradeiro, três eram mercadores, apenas um sapateiro e o outro não declarou o que fazia da vida. ${ }^{11}$

Mapa 7: Praça pequena e os elementos urbanos conforme a descrição de Gabriel Soares de Souza

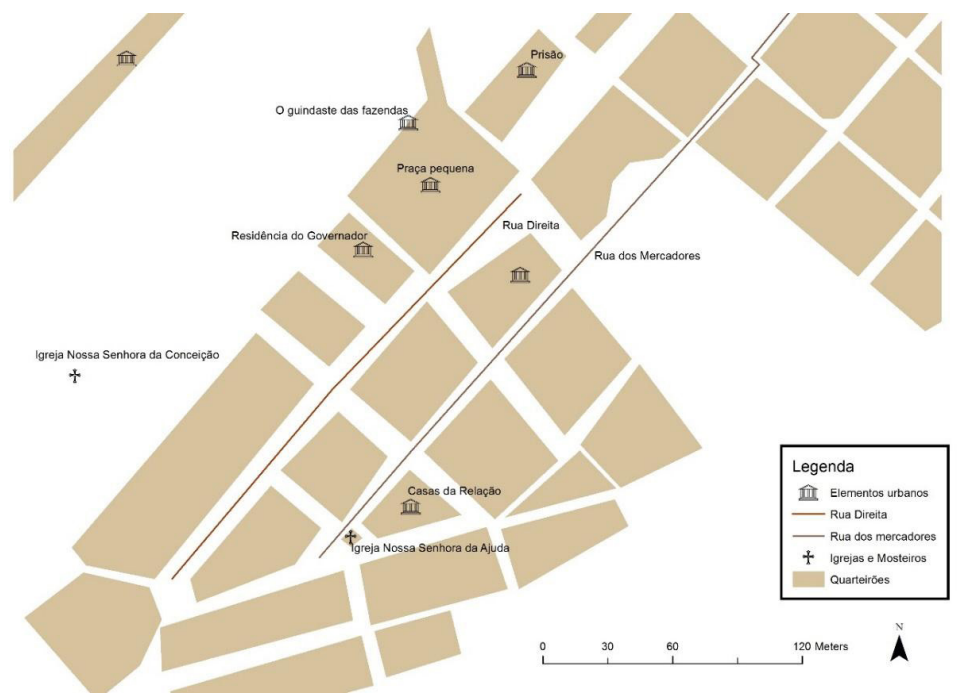

Fonte: Elaboração própria com base na planta de Albernaz e os topônimos descritos por Gabriel Soares de Souza no Tratado descriptivo do Brasil em 1587.

${ }^{10}$ SOUZA, Tratado descriptivo do Brasil em 1587 p. 118.

${ }^{11}$ É possível que a rua direita e a dos mercadores fossem a mesma, como sugere a planta de 1549, de autoria de Theodoro Sampaio, publicada na obra póstuma: História da fundação da cidade de Salvador. Ver no acervo do IHGB - Instituto Histórico e Geográfico Brasileiro. 
Não foi possível localizar todos os envolvidos. O marinheiro Domingos de 56 anos de idade, morador "defronte para o cruzeiro Santo Domingo", assim como Miguel de Sá, de 40, vivia "no beco que vai para a horta do correio". Em outros, os acusados estavam apenas de passagem. Por exemplo, não estava nos planos do português Feliciano de Andrade, de 39 anos, passar tanto tempo na Bahia prestando esclarecimentos, pois seu destino era visitar a esposa em Pernambuco. Cerca de $11 \%$ das pessoas ouvidas moravam fora dos limites da cidade. ${ }^{12}$ A fonte revelou a distância entre algumas freguesias e a cidade de Salvador, de acordo com o relato dos residentes. Ver na tabela 1.

Tabela 1: A distância entre as freguesias e a cidade de Salvador segundo os moradores

\begin{tabular}{c|c}
\hline Lugar & Distância de Salvador em léguas \\
\hline Freguesia Nossa Senhora do Socorro & 7 ou 8 \\
\hline Matoim & 6 \\
\hline Passé & 6 \\
\hline Maré & 3 \\
\hline Pirajá & 2 \\
\hline Rio Vermelho & $1 / 2$ \\
\hline Tapagipe & 1 \\
\hline Sergipe do Conde & 12 \\
\hline Tapoã & 3 \\
\hline
\end{tabular}

Fonte: Livro das confissões e reconciliações que se fizeram na visitação do Santo Ofício na cidade do Salvador da Baía de Todos os Santos, do Estado do Brasil" e 'Livro das Denunciações'-1618. Arquivo Nacional da Torre do Tombo

Posto isto, o processo de georreferenciamento em História implica a renúncia da exatidão, conforme as dificuldades mencionadas acima. Neste trabalho cada "ponto" do mapa (pessoa ou elemento) é uma dúvida. Trata-se de um esboço do cotidiano dos agentes: os espaços de trabalho e a economia, os espaços do poder e da administração, os de ensino, os da fé, do pecado, da diversão, da informação, da circulação de pessoas, da punição etc. Mas não se trata de lugares estanques, fechados e especializados em si mesmos, porque o cotidiano da vida urbana, e mesmo rural, era, e ainda o é, dinâmico e plural.

\footnotetext{
${ }^{12} 18$ no total de 165 registros. Fonte: Base de dados própria, elaborada a partir da leitura das relações de causa que se fizeram na segunda Visitação do Santo Ofício, em 1618. Livro das confissões e reconciliações que se fizeram na visitação do Santo Ofício na cidade do Salvador da Baía de Todos os Santos, do Estado do Brasil e 'Livro das Denunciações- 1618. Arquivo Nacional da Torre do Tombo.
} 
Para tentar adentrar os espaços, não poupamos os pormenores de cada depoimento como nomes, testemunhas, genealogias, locais do delito, da residência, enfim, toda riqueza de detalhes sobre as freguesias e pontos urbanos. Este esboço visa construir visualizações sobre a cidade a partir das percepções de seus moradores. Não se trata de apresentar um mapa finalizado, mas permitir a observação dinâmica desses relatos "estrada abaixo", "rio acima", "de fronte para" ou "atrás do".

\section{A cidade de Salvador}

Segundo Betina Schurmann, algumas cidades coloniais brasileiras foram planejadas em meados do século XVII para atender as necessidades de proteção. ${ }^{13}$ Dentre elas estaria Salvador que sofreu com ameaças internas e externas, as incursões indígenas e o corso neerlandês. As mudanças no urbanismo desempenham a função de demonstrar a importância política e as aspirações imperiais da Câmara local. ${ }^{14}$ Assim, o argumento do planejamento se confronta com a interpretação tradicional de "caos espontâneo" que ressalta as ruas consideradas medievais e tortuosas do urbanismo português. Este modelo foi severamente atacado e comparado ao vizinho espanhol, supostamente superior pela disciplina de suas ruas paralelas e de seu traçado xadrez. ${ }^{15}$

Para Schurmann, os modelos de urbanização obedeceram às particularidades da colonização, sobretudo o desenvolvimento das atividades econômicas. O modelo português se caracterizaria pela dependência do espaço rural. As cidades seriam apêndices dos núcleos rurais responsáveis pela produção colonial, como a da cana de açúcar por exemplo. Enquanto por sua vez, os vizinhos espanhóis mantinham suas atividades nos centros urbanos, a extração da prata precisava de outras atividades complementares para o seu funcionamento, formando uma cadeia de interdependência entre os núcleos urbanos. Além disso, outro fator importante do modelo hispano seria a

\footnotetext{
${ }^{13}$ SCHURMANN, Betina. Urbanização colonial na América Latina: cidade planejada versus desleixo e caos, Textos de História 7, n 1/2 (1999): 149-78.

${ }^{14}$ MARQUES, Guida. "Por ser cabeça do Estado do Brasil". As representações da cidade da Bahia no século XVII", in Salvador da Bahia: retratos de uma cidade atlântica, org. Evergton Sales Souza e Hugo Ribeiro da Silva, Coleção Atlântica (Salvador : Lisboa: EDUFBA ; CHAM, 2016), 17-43.

${ }^{15}$ SCHURMANN, "Urbanização colonial na América Latina: cidade planejada ver sus desleixo e caos". ver também o capítulo 4: Semeador e o ladrilhador, na obra Sérgio Buarque de Holanda, Raízes do Brasil, 7. impr (São Paulo: Companhia das Letras, 1999).
} 
existência de grandes cidades com populações expressivas antes mesmo da chegada dos conquistadores. ${ }^{16}$

Para Guida Marques as transformações no urbanismo de Salvador, na segunda metade do seiscentos, testemunham as aspirações e os esforços da câmara municipal para elevar o status da cidade, que carregava com orgulho o título de "Cabeça do Estado do Brasil", e era porto estratégico para o Império, fazendo frente às capitanias de Pernambuco e Rio de Janeiro. ${ }^{17}$

Segundo Nestor Goulart Reis Filho, o urbanismo colonial foi inspirado no modelo medieval português, porque os prédios definiam os contornos das ruas. Na ausência de pavimentos, os contornos das edificações se transformaram no contorno das ruas, que por sua vez formavam as quadras, logo, "seria impossível pensar em ruas sem prédios; ruas sem edificações definidas por cerca, eram as estradas". ${ }^{18}$ As casas urbanas (as térreas e os sobrados) se caracterizavam pelo aproveitamento de todo terreno, sem deixar recuo para áreas externas ou construção de jardins. As portas e janelas estavam diretamente sobre a rua. As acomodações mais afastadas tinham plantas distintas, pois contavam com o espaço externo. As únicas construções que fugiam a esta regra seriam as chácaras, porque relativamente próximas das cidades contavam com o melhor dos dois mundos: o espaço externo dos casarões rurais e a facilidade do abastecimento típico das cidades.

Se para Filho a ausência de jardins públicos e privados davam feição ao urbanismo português, o mesmo não acontecia com as árvores frutíferas, caídas sobre os muros dos sobrados, conforme a descrição de Gabriel Soares de Souza. Nos quintais havia palmeiras carregadas de cocos, tâmaras, laranjeiras, figueiras, romeiras e parreiras. A cidade de Salvador foge mais uma vez à interpretação clássica sobre o urbanismo colonial quando o cronista revela as hortas e um rio que cercavam a cidade pelo lado da terra. ${ }^{19}$

Aparentemente, as pessoas mais abastadas de Salvador moravam nos casarões situados no norte da praça grande (Chamada por Gabriel Soares de Souza de terreiro grande), onde eram realizadas as festas a cavalo, perto das árvores frutíferas, atrás do Colégio dos Padres da Companhia. ${ }^{20}$

\footnotetext{
${ }^{16}$ SCHURMANN, “Urbanização colonial na América Latina: cidade planejada versus desleixo e caos".

${ }^{17}$ MARQUES, ““'Por ser cabeça do Estado do Brasil”. As representações da cidade da Bahia no século XVII”.

${ }^{18}$ FILHO, Nestor Goulart Reis. "Lote urbano e arquitetura no Brasil”, in Quadro da arquitetura no Brasil, $9^{\circ}$ ed. (São Paulo: Editora Perspectiva, 2000), 21-53 p.22.

${ }^{19}$ SOUZA, Tratado descriptivo do Brasil em 1587 p.119.

${ }^{20}$ SOUZA p.121.
} 
Mapa 8: Terreiro Grande e as casas nobres

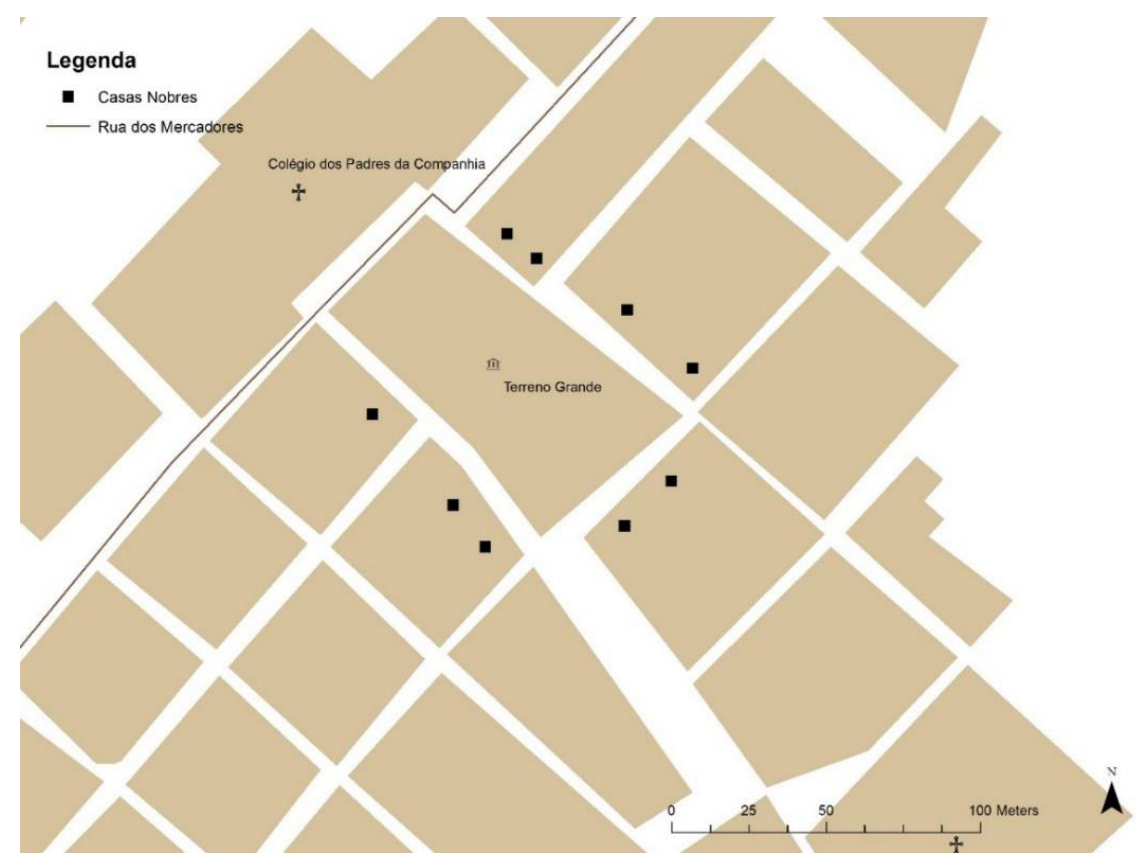

Fonte: Elaboração própria com base na planta de Albernaz e os topônimos descritos por Gabriel Soares de Souza no Tratado descriptivo do Brasil em 1587.

Nos arredores viviam alguns envolvidos na visitação de 1618. Na banda norte, depois do "Terreiro Grande", na rua do terreiro de São Francisco, estavam Álvaro Sanches o escrivão da chancelaria de idade de 60 anos; Manuel Gonçalves, lavrador de mandioca de 40, e Pero Gonçalves, natural da Ilha da Madeira, de 16 anos, que dedicava seu tempo ao estudo da gramática. Ao lado esquerdo, tomando o terreno grande do mapa 8 como referência, vivia em um dos casarões o mercador Miguel de Abreu, natural de Guimarães, de 40 anos. ${ }^{21}$

No Colégio dos Padres da Companhia, habitavam Jorge Monis e Simão Pinheiro. $O$ primeiro era natural de Lisboa, com idade de 28 anos e estudante de Filosofia. ${ }^{22} \mathrm{O}$ segundo era padre reverendo do Colégio com 48 anos de

\footnotetext{
${ }^{21}$ Base de dados própria, elaborada a partir da leitura das relações de causa que se fizeram na segunda Visitação do Santo Ofício, em 1618.

${ }^{22} \mathrm{O}$ padre Fernão Cardim descreve em sua obra uma procissão das virgens organizada pelos estudantes do Colégio da Companhia. Além disso, lista os bens doados por um certo homem ao Colégio, cerca de 8 mil cruzados em terras, gado e escravos, o que dá uma dimensão do prestígio que gozava a ordem. Ver em: Cardim, Narrativa epistolar de uma viagem e missão jesu... p. 78-79.
} 
idade. 0 colégio foi reduto dos eruditos e das reuniões das elites, reforçando o prestígio da ordem religiosa. ${ }^{23}$ Pela descrição de Gabriel Soares de Souza, no capítulo IX, tratava-se de um prédio opulento e vistoso:

Tem esto collegio grandes dormitórios e muito bem acabados, parte dos quaes ficam sobe o mar com grande vista; cuja obra é de pedra e cal, com todas as escadas, portas e janelas de pedrarias, com agua muito boa dentro, e ao longo do mar tem umas terracenas, onde recolhem o que lhe vem embarcado de fora. Tem este collegio ordinariamente oitenta religiosos, que se ocupam em pregar e confessar alguma parte d'elles, outros ensinam latim, artes, teologia e casos de consciência, com o que tem feito muito fruto na terra; o qual está muito rico, porque tem S.M. cada unno quatro mil cruzados e da vantagem, e importa-lhe-há a outra renda que tem na terra outro tanto, porque tem muitos curraes de vaccas, onde se afirma que trazem mais de duas mil vaccas de ventre, que nesta terra parem todos os annos. (SOUZA, 1587. p.121).

$\mathrm{Na}$ "Rua dos Mercadores" (Mapa 11) viveram seis envolvidos. Pero Villela de 53 anos, se ocupava como cirurgião, o mercador Matheus Mendes de 25, o barbeiro João Rodrigues de 28, Balthazar d'Araújo com apenas 18, o também barbeiro Francisco Nogueira, de 30, e o mercador Balthesar Ferreira, de 40 anos. Pero Villela não sabia nem mesmo onde havia nascido. Procurou o Tribunal para aliviar suas culpas pelas proposições heréticas que disseminou por ser ignorante, garantiu ele. Matheus Mendes se acusou de atos nefandos com o cozinheiro do governador, depois das "Portas de Santa Luzia" e fora dos muros que cercavam a cidade (mapas 9 e 10$){ }^{24}$

\footnotetext{
${ }^{23}$ MARQUES, "Por ser cabeça do Estado do Brasil". As representações da cidade da Bahia no século XVII"... ${ }^{24}$ Base de dados própria, elaborada a partir da leitura das relações de causa que se fizeram na segunda Visitação do Santo Ofício, em 1618.
} 
Mapa 9: Planta da cidade de Salvador com os prédios religiosos, prédios da administração e elementos urbanos

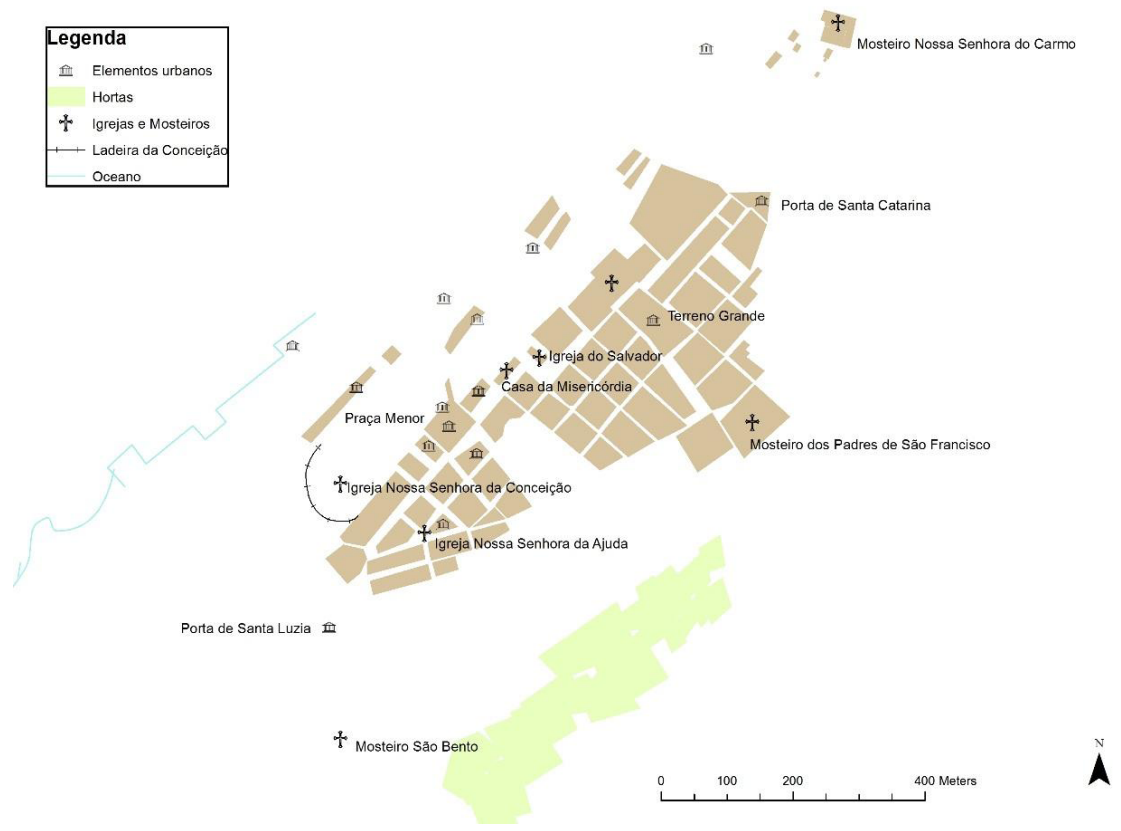

Fonte: Elaboração própria com base na planta de Albernaz e os topônimos descritos por Gabriel Soares de Souza no Tratado descriptivo do Brasil em 1587.

Mapa 10: Cidade de Salvador vista da baía (Mapa de Hassel Gerritsz)

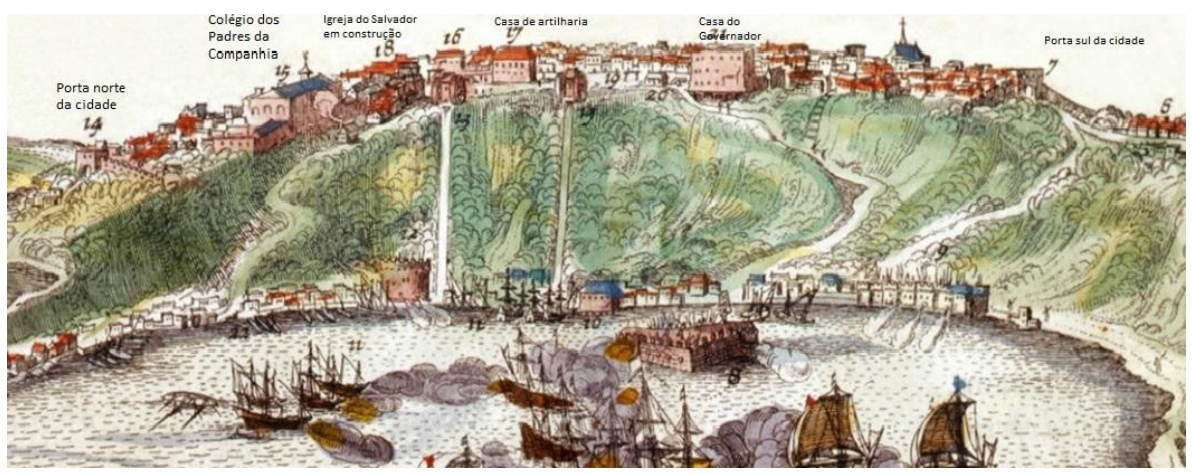

Fonte: Joannes de Laet. Beschrijvinghe van West-Indien. Bij de Elzeviers, Tot Leyden. p. 501-552. 
João Rodrigues entregou Antônio Velho, seu amigo desde quando ainda viviam na cidade do Porto, e então vizinho em Salvador. Mesmo depois de perguntado se estava em seu perfeito juízo ou se havia bebido vinho quando ouviu o dito amigo proferir heresias contra o Tribunal, manteve a denúncia. $\mathrm{E}$ pelo mesmo motivo Balthazar d'Araújo, residente na dita rua dos mercadores na altura do Colégio, na casa do mercador Pero João Landim, denunciou João Vaz Serrão, homem nascido na Bahia e morador em Pirajá. O cristão velho Francisco Nogueira confessou ter se valido das práticas de adivinhação com ajuda de um escravo velho dos padres do Mosteiro de São Francisco, para encontrar sua escrava fugida. Sendo perguntado sobre o escravo feiticeiro, disse não saber seu nome, mas que no ritual usava apenas uma tigela, e que seu irmão Paulo Correa, morador de Salvador, poderia servir de testemunha. ${ }^{25}$

O último desta rua era Balthesar Ferreira, um mercador e cristão velho assolado pelo medo do Édito de Fé que decidiu confessar as culpas de um passado remoto de vinte anos atrás, porém o mal-estar não passou de meia dúzia de proposições heréticas. ${ }^{26}$

Nas proximidades do Mosteiro dos Padres de São Francisco, moravam outros quatro homens. Domingos de Serpa, dedicado ao comércio, de aparência de 36 anos, compareceu sem ser chamado ao Colégio dos Padres para confessar que, junto com seu amigo Pero Vilela, havia pecado por discutir sobre os graus de importância dos santos da Igreja Católica. O escrivão da chancelaria, Alvaro Sanches, compareceu para entregar Diogo Dias, porque certo dia, em um dos guindastes da cidade (Mapa 11) usados para transportar o carregamento pesado para a cidade alta, ambos discutiram sobre práticas judaicas. ${ }^{27}$

No mesmo local, também morava gente mais humilde como o lavrador de mandioca Manuel Gonçalves e sua esposa Margarida Pinta. Estavam escandalizados com os flagelos que a vizinha Maria impusera a um crucifixo em plena madrugada. Margarida, porém, não pôde denunciar pela sua condição de cega, mandando o marido em seu lugar. ${ }^{28}$

O último ocupante da rua de São Francisco era o estudante da segunda turma de gramática do Colégio dos Padres da Companhia, Pero Gonçalves, de 17 anos de idade. No seu relato acusou Domingos Alvares de Serpa de comer

\footnotetext{
${ }^{25}$ Base de dados própria, elaborada a partir da leitura das relações de causa que se fizeram na segunda Visitação do Santo Ofício, em 1618.

${ }^{26}$ Idem;

${ }^{27}$ Idem;

${ }^{28}$ Idem;
} 
carne em dias santos. Afirmou que o acusado era afamado na cidade por ser um traficante muito rico. Seus companheiros de classe, Amador de Lima, de 15 anos, e Salvador Monteiro, poderiam ser testemunhas das referidas heresias. Filho de um lavrador de cana e nascido em Salvador, a segunda testemunha estava na primeira classe de gramática, aos 17 anos de idade. ${ }^{29}$

Voltando ao "terreiro grande" e seguindo na direção sul, no final da "rua dos mercadores" estava situada a Igreja da Nossa Senhora da Ajuda, que segundo Gabriel Soares de Souza foi a antiga Igreja Sé. ${ }^{30}$ Viviam ali os denunciantes Melchior Gonçalves Barreto e Francisco de Barbuda. ${ }^{31}$

No caso de Melchior encontramos menções sobre a cidade e o recôncavo. A heresia teria acontecido durante uma procissão que passou pela "rua da cadeia", próximo à casa do governador. 0 acusado, seu amigo de oito anos, chamava-se Duarte Rodrigues e morava em Passé. As testemunhas eram os seus amigos Bartholomeu Pires, morador em Matoim, Melchior Gonçalves, criador de gado e morador em Sergipe del Rei, Gaspar Gonçalves, também de Sergipe del Rei, e o famoso mercador Manuel Nunes, da Travessa da Misericórdia.

A "rua direita", nome comum às cidades do urbanismo português, ${ }^{32}$ concentrava a maior parte dos confitentes do período da graça $a^{33}$ na segunda Visitação. ${ }^{34}$

Um deles é o sapateiro Frutuoso Antunes, de 55 anos, que segundo o inquisidor aparentava ter pouco juízo e entendimento. Ele confessou ter duvidado da pureza da virgem antes do nascimento de Cristo. E deu por testemunhas a sua esposa Maria Gonçalves, os filhos Antônio e Domingos, o primeiro com 18 ou 20 anos, o segundo entre 13 e $14 . .^{35}$

\footnotetext{
${ }^{29}$ Base de dados própria, elaborada a partir da leitura das relações de causa que se fizeram na segunda Visitação do Santo Ofício, em 1618.

${ }^{30}$ SOUZA, Tratado descriptivo do Brasil em 1587 p. 123.

${ }^{31}$ Base de dados própria.

${ }^{32}$ SCHURMANN. "Urbanização colonial na América Latina: cidade planejada ver sus desleixo e caos".

${ }^{33}$ Período de trinta dias em que os cristãos eram convidados a confessar de espontânea vontade, com a promessa de pena branda. Ver em: VAINFAS, Ronaldo. org., Confissões da Bahia (Companhia das Letras, 1997).

${ }^{34}$ Base de dados própria.

${ }^{35}$ Base de dados própria, elaborada a partir da leitura das relações de causa que se fizeram na segunda Visitação do Santo Ofício, em 1618.
} 
Mapa 11: A localização de confitentes e denunciantes na Segunda Visitação do Santo Ofício. E a concentração das confissões na banda sul da cidade

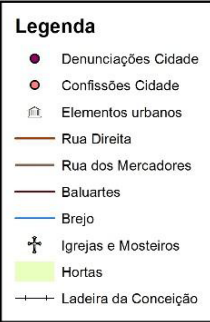

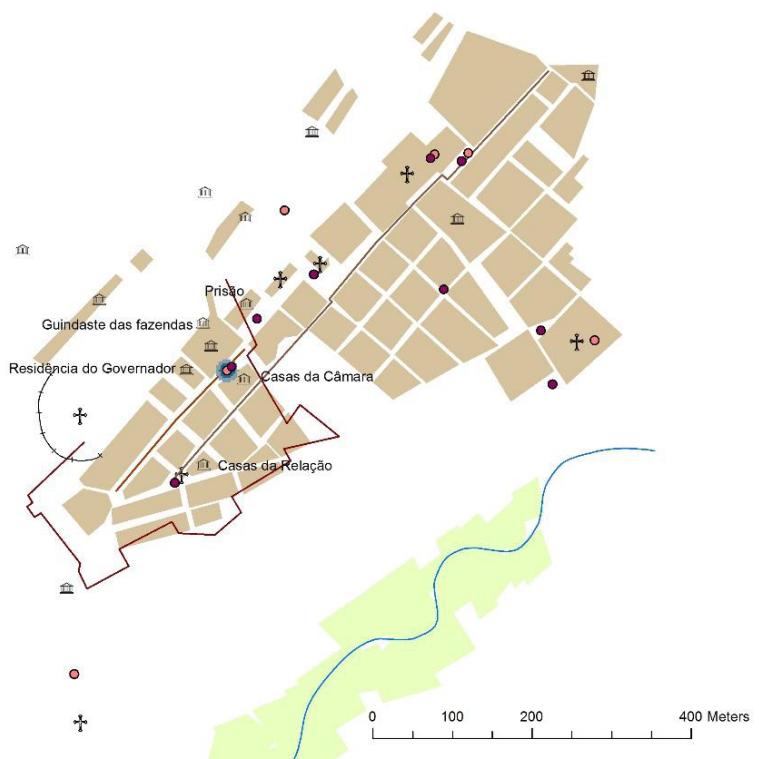

Fonte: Elaboração própria com base na planta de Albernaz (1612); nos topônimos descritos por Gabriel Soares de Souza no Tratado descriptivo do Brasil em 1587 e nos registros inquisitoriais da segunda visitação (1618).

Na mesma rua vivia o mercador Duarte Aluz Ribeiro, que, embora fosse considerado mancebo por parte dos inquisidores, em 1618 já se encontrava casado e ocupante do cargo de tesoureiro da confraria de Nossa Senhora da Ajuda. Ele se declarou culpado por tratar com desrespeito uma imagem de São Pedro durante o período de quaresma na mesma igreja em que desempenhava a função. E quando perguntaram se conhecia algum culpado em matéria da fé, respondeu que não. ${ }^{36}$

Francisco de São Paio Aranha foi o último confitente da rua a jurar diante dos sacramentos. Trazia consigo a consciência pesada pelo pecado da sodomia. Cometeu por três vezes no Mosteiro de Nossa Senhora do Socorro da Ordem de São Francisco da Recoleta, mas havia se arrependido e agora se encontrava casado, ocupando seu tempo no comércio. ${ }^{37}$

\footnotetext{
${ }^{36}$ Base de dados própria, elaborada a partir da leitura das relações de causa que se fizeram na segunda Visitação do Santo Ofício, em 1618.

${ }^{37}$ Idem;
} 
As denúncias da rua direita foram feitas por Belchior Fernandes de Bastos e Antônio Nunes, mercadores. Belchior disparou acusações contra o também mercador Nicolau Maia, pois descobriu que a mãe de Nicolau caíra no pecado nefando com uma tal Violante de Salvador, e que estaria escondida em Pernambuco. Logo depois acusou o vizinho de Nicolau Maia, outro mercador, Simão Nunes de Matos. Matos teria realizado festejos e matinadas aos sábados junto com outros comerciantes portugueses, Francisco Tinoco, Diogo Fernandes, Manuel Alvares de Galego, Paschoal Bravo, e os cunhados Simão Machado e Simão Leão, os dois últimos contratadores dos dízimos do açúcar. ${ }^{38}$

E por fim, a confissão de Antonio Nunes, de 30 anos, que foi anotada no livro de denunciações por engano. 0 escrivão rapidamente reparou o erro informando que o depoimento continuaria no livro das confissões, na folha quinze. 0 dito Nunes não sabia ler e escrever, era filho de um alfaiate do reino que abandonou o ofício para servir como marinheiro na nau de Bom Jesus, marinheiro que terminou seus dias desaparecido no mar. Deixou esposa e três filhos. A mãe de Nunes casou suas irmãs, Maria e Joana Nunes, mas o infortúnio permaneceu na família, pois o marido de uma das filhas teria ficado cego. Em busca de melhorar a sorte da família, Antônio mudou-se para Salvador com sua esposa Antônia Rosa, com quem morava na "Rua Direita", ganhando a vida como vendeiro. ${ }^{39}$

\section{O recôncavo baiano}

Os demais implicados residiam fora da cidade, conforme o mapa a seguir (Mapa 12). Não podemos deixar de notar que parte dos denunciantes se concentrava à direita da baía, enquanto os confitentes estavam dispersos da Ponta do Padrão ${ }^{40}$, seguindo rumo ao norte, cruzando o rio Paraguaçu até a Ilha de Itaparica. ${ }^{41}$

\footnotetext{
${ }^{38}$ Idem;

${ }^{39}$ Idem;

${ }^{40}$ Topônimo usado por Gabriel Soares de Souza. SOUZA, Tratado descriptivo do Brasil em 1587 P. 127.

${ }^{41}$ Base de dados própria, elaborada a partir da leitura das relações de causa que se fizeram na segunda Visitação do Santo Ofício, em 1618.
} 
Mapa 12: Confissões e denunciações do Recôncavo Baiano

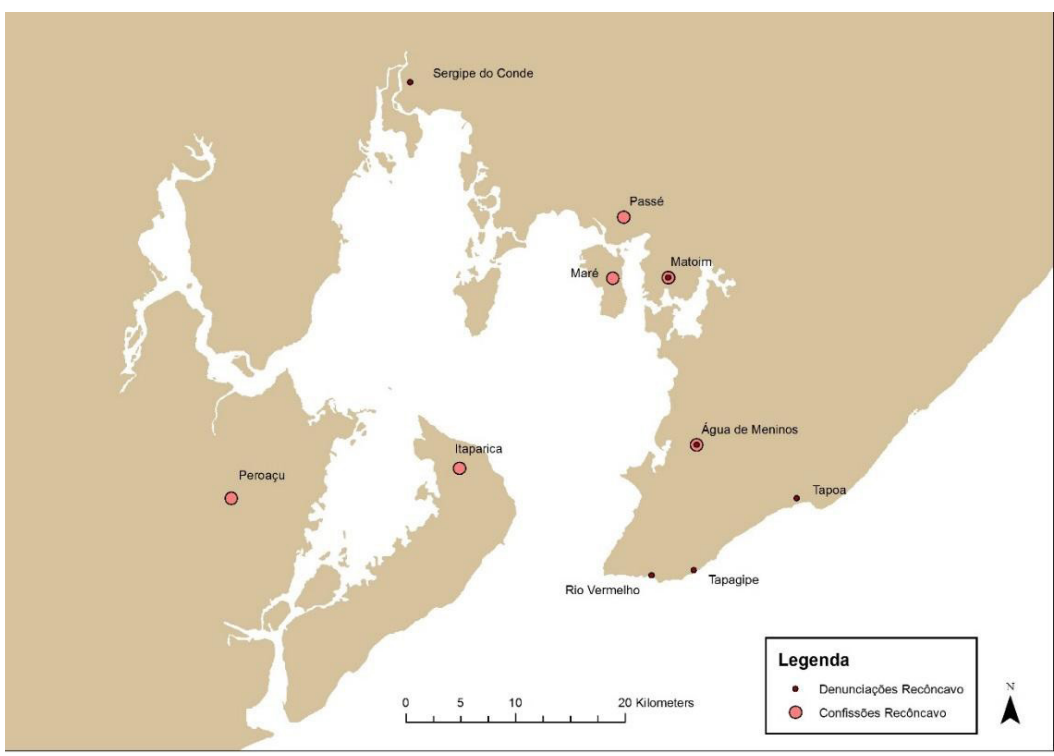

Fonte: Gabriel Soares de Souza no Tratado descriptivo do Brasil em 1587 e registros inquisitoriais da segunda visitação (1618).

Mapa 13: Confissões do recôncavo

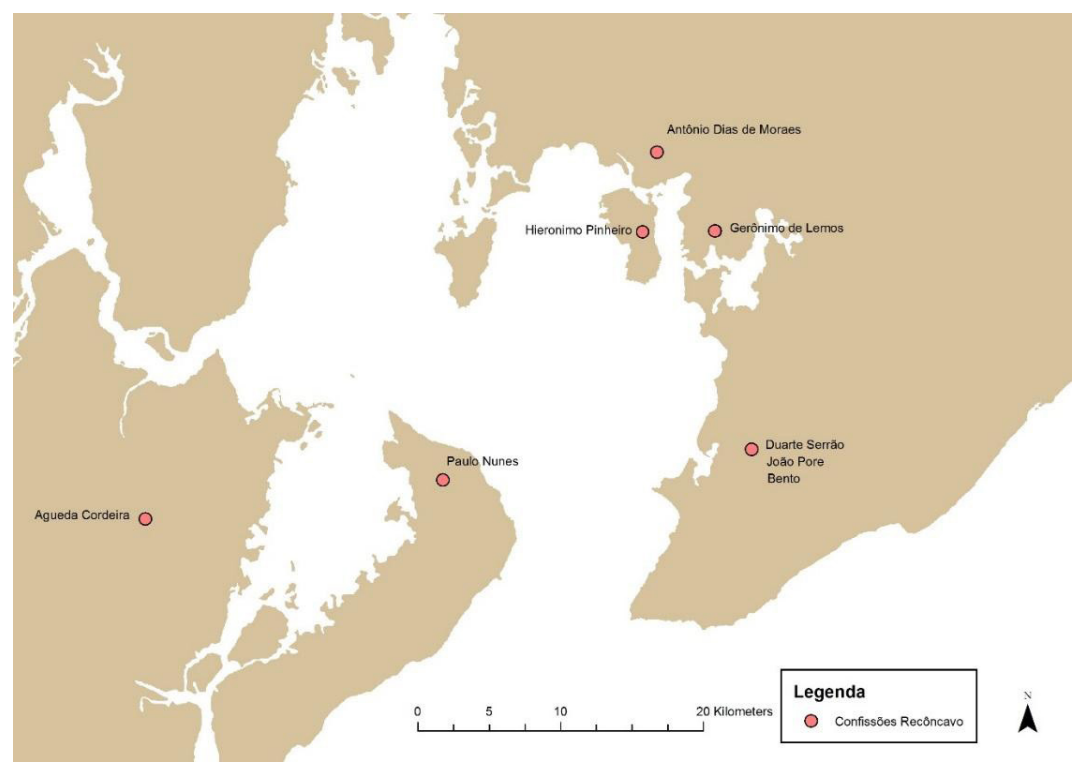

Fonte: Gabriel Soares de Souza no Tratado descriptivo do Brasil em 1587 e registros inquisitoriais da segunda visitação (1618). 
Mapa 14: Denunciações do recôncavo

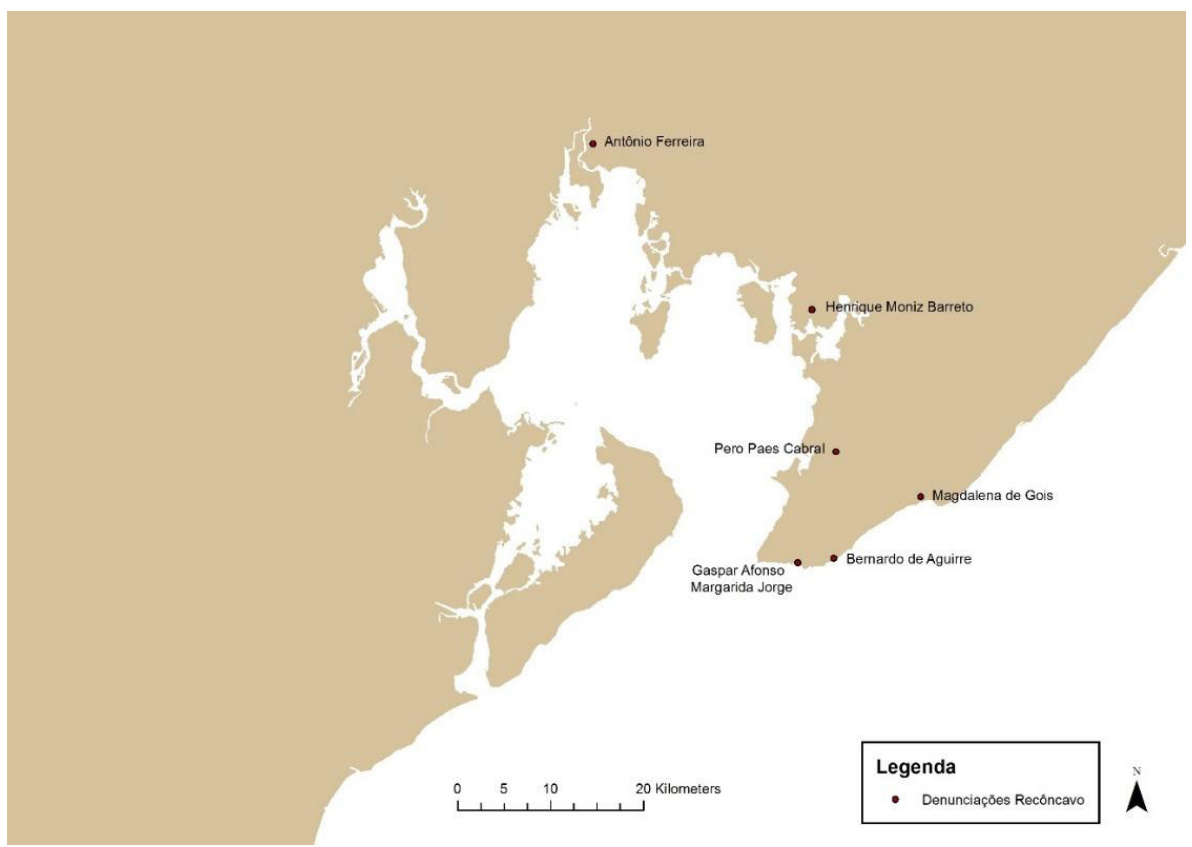

Fonte: Gabriel Soares de Souza no Tratado descriptivo do Brasil em 1587 e registros inquisitoriais da segunda visitação (1618).

Na Ponta do Padrão (Rio Vermelho, Tapagipe e Tapoã), moravam Gaspar Afonso, Margarida Jorge, Bernardo de Aguirre e Magdalena de Góis. Gaspar Afonso foi, com certeza, uma das pessoas que mais realizou denúncias na mesa do visitador. Dentre as mais relevantes estava a história que ouviu de um amigo chamado Matheus Souza. Matheus teria visto seu tio Pedro Fernandes Raphael escrever em um livro da confraria dos judeus, a portas fechadas no seu comércio à noite. $O$ cúmplice do tio era o comerciante Luis Lopes Parede, que ora lavrava cana. O tio faleceu, mas deixou a herança para quatro filhas; a fonte indica o paradeiro apenas de três delas, duas na Bahia e uma no Rio de Janeiro. Gaspar Afonso não poupou nem mesmo o padre Antônio Neto, a quem responsabilizou por solicitar mulheres no ato da confissão. ${ }^{42}$

A última denúncia foi contra Pero Garcia. Gaspar Afonso trabalhava para Pero Garcia organizando seus livros de contas, e em certa ocasião, em

\footnotetext{
${ }^{42}$ Base de dados própria, elaborada a partir da leitura das relações de causa que se fizeram na segunda Visitação do Santo Ofício, em 1618.
} 
seu escritório, encontrou uma carta suspeita. A carta teria sido escrita pelo irmão de Garcia, o senhor de engenho Diogo Fernandes, e parecia tratar de assuntos judaicos. No final havia o pedido para que a destruísse depois de lê-la. Em seguida, acusou Pero Garcia do pecado de nefando e apontou duas de suas escravas como testemunhas, Juliana e Inês. ${ }^{43}$

Essa não foi a primeira denúncia contra Pero Garcia por nefando, aparentemente era um caso notável na cidade a ponto de ter sido excomungado pelo bispo. Na confissão de Bento, de 16 anos de idade, cativo do próprio, e filho de sua escrava Francisca com um mameluco, há alguns detalhes, como os lugares do ocorrido: uma vez no engenho do rio Pitanga e outra no terreiro que era propriedade sua na cidade de Salvador. ${ }^{44}$

Na mesma estrada de Rio Vermelho, próximo à porta de Santa Catarina, estava Margarida Jorge, mulher que foi de Diogo Simões lavrador de cana, de idade avançada, que não poupou as pessoas que a acolheram como membro da família havia 12 anos. Margarida suspeitou que Felipa Gonçalves e Margarida Diniz mantinham práticas de "cerimônia da lei velha", como comer carne com azeite durante uma boda e em outras ocasiões ter retirado a gordura da carne antes de salgá-la. ${ }^{45}$

Em Tapagipe, próximo à cidade, região proveitosa com olarias, currais de vacas, incluindo o curral dos Garcia d'Ávila ${ }^{46}$, família da qual falaremos adiante, morava Bernardo de Aguirre. De família grande, quase toda residente na Bahia, incluindo seu pai, o capitão do forte de São Phelipe, morador na rua direita, Bernardo se pôs no tribunal contra o advogado Phelipe Thomás de Miranda, que seria um afamado blasfemador e sodomita. ${ }^{47}$

Em uma procissão no período da quaresma, presenciou os escárnios contra a imagem do Cristo proferidos pelo dito Phelipe Thomás e Luis Alvares, caixeiro de Manuel Sanches. E deu por testemunhas alguns de seus familiares, o irmão Francisco Silva, casado e residente em Lisboa, mas que transitava entre Salvador e Angola. Outras testemunhas foram o seu cunhado Diogo Sandoval, mexicano de nação, que havia casado na Bahia e nela se encontrava residente, e os seus irmãos Dona Isabel, Diogo Gonçalves Lasso e Francisco

\footnotetext{
${ }^{43}$ Idem;

${ }^{44}$ Idem;

${ }^{45}$ Idem;

${ }^{46}$ SOUZA p.46.

${ }^{47}$ Base de dados própria, elaborada a partir da leitura das relações de causa que se fizeram na segunda Visitação do Santo Ofício, em 1618.
} 
Quaresma, os dois últimos envolvidos no pecado nefando com o mesmo advogado. Bernardo de Aguirre também sabia de outros portugueses moradores em Salvador que pecavam com Thomás, incluindo Antônio Roiz, seu criado, e um tal Bento Correia. ${ }^{48}$

Há duas léguas de Rio Vermelho, em Tapoã, encontrava-se a viúva Magdalena de Gois que compareceu à mesa para denunciar os próprios filhos. Disse ter tomado consciência de que seu filho mais novo, Manuel Macedo, estudante, teria cometido torpezas com o irmão mais velho, já defunto, e outras pessoas da cidade. E que a mulata Luzia Pereira, esposa do vendedor de vinhos em Tapoã, Domingo Gonçalves, poderia confirmar toda a história. E ainda culpou o vigário de Jaguaripe, o padre Balthesar Marinho, por solicitá-la no ato da confissão, como teria feito a outras mulheres. ${ }^{49}$

Não muito distante, em Água de Meninos moravam outros três cristãos. Segundo Guida Marques, essa região foi fruto do primeiro projeto urbanístico da câmara municipal de Salvador no processo de expansão pelo Recôncavo, na segunda metade do século XVII, para atender a população crescente. ${ }^{50} \mathrm{O}$ plano de expansão consiste ainda na criação de poços e em melhorias nas condições de salubridade de modo geral. Gabriel Soares de Souza considerou a região próspera, onde se estabeleceram os engenhos dos homens mais importantes da Bahia, como Christovam de Aguiar. ${ }^{51}$

A documentação também se reporta a Duarte Serrão, certamente um dos primeiros colonos nascidos no recôncavo. O lavrador de mandioca de 50 anos de idade confessou ser herege apostato da santa fé católica, e que de suas blasfêmias já havia pedido perdão em outras oportunidades, como na primeira visitação realizada por Heitor Furtado de Mendonça em 1591, quando foi preso e penitenciado. ${ }^{52}$

João Poré, flamengo de sobrenome, de mais ou menos 30 anos de idade, morador na Torre dos Garcia d'Ávila, confessou ter usado um remédio caseiro que teria aprendido em Madrid com alguns italianos para aliviar a dor de dente. A prática consistia em tocar o dente enfermo com um prego novo e escrever com ele, na parede, a palavra "Macabeus". Se o dente estivesse

\footnotetext{
${ }^{48}$ Idem;

${ }^{49}$ Idem;

${ }^{50}$ MARQUES, ““”Por ser cabeça do Estado do Brasil”. As representações da cidade da Bahia no século XVII”.

${ }^{51}$ SOUZA, Tratado descriptivo do Brasil em 1587 p. 131.

${ }^{52}$ Sobre as confissões que se fizeram na visitação de 1591, ver em: VAINFAS, Ronaldo, org. Confissões da Bahia. Companhia das Letras, 1997.
} 
ao lado direito, pregava o prego na primeira letra " $\mathrm{A}$ " da mesma palavra, se estivesse no esquerdo, pregá-lo-ia no último "A". Tal superstição mostra quão abundante é o campo da religiosidade popular a ponto de João Poré prescrevê-la a outros conhecidos acometidos pelo mesmo mal. ${ }^{53} \mathrm{E}$ deu por testemunha o senhor da torre onde vivia, Francisco Dias d'Ávila, membro de uma das famílias mais importantes no processo de exploração do interior do sertão nordestino. O nome Francisco Dias d'Ávila se repetia em cada geração da família, estando João Poré a serviço do primeiro deles. ${ }^{54}$

Francisco Pinheiro Coutinho, morador em Passé, tinha pendências familiares para acertar. Acusou o próprio genro por suposto ajuntamento carnal com sua filha antes do matrimônio. Também dirigiu acusações ao seu compadre Antônio Dias de Moraes, antigo "dizimeiro"55 da Bahia que havia se tornado lavrador de cana na freguesia de Passé. ${ }^{56}$

Passando a "boca do rio Matoim", zona de muitas fazendas nobres ${ }^{57}$, residia o fidalgo Henrique Moniz Barreto, senhor de engenho e antigo juiz ordinário da câmara. Aparentemente, Barreto viu na denunciação uma oportunidade de corrigir os desvios dos potentados locais que foram ocultados ou minimizados pelas autoridades baianas. Provavelmente, supôs que os licenciados recém-chegados estariam mais inclinados a imparcialidades ou teriam menos tempo para se familiarizar com redes de intriga. ${ }^{58}$

Barreto acusou de judaizar o senhor de engenho Balthezar Ribeiro e seu irmão Antônio Ribeiro, que andava por Angola na ocasião. Disse tê-los visto com uma bíblia da lei antiga, no tempo em que levava sua cana para moagem no engenho de Ribeiro. E que tudo indicava se tratar de um dos cinco mil exemplares desembarcados de Flandres no porto de Salvador, segundo a conversa que ouviu dos padres do Colégio da Companhia. ${ }^{59}$

\footnotetext{
${ }^{53}$ Sobre religiosidade popular, SOUZA, Laura de Mello e. O diabo e a Terra de Santa Cruz: feitiçaria e religiosidade popular no Brasil colonial. São Paulo: Companhia das Letras, 1986.

${ }^{54}$ Ver em: PESSOA, Ângelo Emílio da Silva. "As ruínas da tradição: A casa da Torre de Garcia d'Ávila - família e propriedade no nordeste colonial.” (São Paulo, SP, USP - Universidade de São Paulo, 2003) p. 224.

${ }^{55}$ Coletor do imposto do dízimo sob o açúcar

${ }^{56}$ Base de dados própria, elaborada a partir da leitura das relações de causa que se fizeram na segunda Visitação do Santo Ofício, em 1618.

${ }^{57}$ Possuía inclusive um engenho de bois de duas moendas que foram de Gaspar Dias Barboza. SOUZA, Tratado descriptivo do Brasil em 1587.

${ }^{58}$ Base de dados própria, elaborada a partir da leitura das relações de causa que se fizeram na segunda Visitação do Santo Ofício, em 1618.

${ }^{59}$ Idem;
} 
O desentendimento entre Barreto e Ribeiro era mais antigo, datava do período em que serviu como juiz ordinário na Câmara de Salvador. Nessa ocasião, teria encontrado irregularidades em um lote de azeite importado por Balthezar Ribeiro. 0 acusado blasfemou no ato do flagrante, levando o então juiz a encaminhar o caso ao bispo da cidade sem sucesso, pois Dom Constantino Barradas era muito amigo de Ribeiro. E indicou outros nomes da câmara que poderiam confirmar a história: Afonso da Gama Botafogo (vereador); Sebastião de Cavelos (vereador) e Bartholomeu Pirez (o então procurador do conselho) ${ }^{60}$

A Ilha da Maré, de fronte para a freguesia de Passé, a uma distância de seis léguas da cidade de Salvador, era terra boa para os canaviais e o cultivo de mantimentos: ${ }^{61}$

“(...) onde está um engenho de assucar que lavra com bois, que é de Bartholomeu Pires, mestre da capella da Sé, aonde estão assentados de sua mão passante de vinte moradores, os quaes tem aqui uma igreja de Nossa Senhora das Neves (...)" (SOUZA, 1587.p.130)

A ilha era domicílio do padre confitente Hieronimo Pinheiro, 55 anos, e que há nove solicitou a esposa do mestre de açúcar Bertolomeu Leitão, na freguesia de Jaguaripe, onde foi capelão. ${ }^{62}$

Em Passé encontrava-se Antônio Dias de Moraes que usou a estratégia de atacar para se defender, porque não sabia quem poderia prejudicá-lo e, na dúvida, listou todos os seus desafetos. Confessou ter blasfemado durante uma conversa com Francisco Pinheiro Coutinho e que ambos se tornaram inimigos por demandas sobre as madeiras de jacarandá na fazenda que possuíam em conjunto, e por isso pedia perdão..$^{63}$

Em Sergipe do Conde outra conversa sem propósito terminou em heresia. Antônio Ferreira, o ferreiro do engenho de João Ramos Pereira, discutiu com o vendeiro de vinho Gonçalo Corrêa e o mestre de açúcar João Garcia, sobre fornicação. Os homens defendiam a ideia de que com negras não era pecado mortal para Deus. Ferreira escandalizou com tal proposição e apontou o feitor Francisco Dias como testemunha. ${ }^{64}$

\footnotetext{
${ }^{60} \mathrm{Idem} ;$

${ }^{61}$ SOUZA p. 129.

${ }^{62}$ Base de dados própria, elaborada a partir da leitura das relações de causa que se fizeram na segunda Visitação do Santo Ofício, em 1618.

${ }^{63}$ Idem;

${ }^{64}$ Idem;
} 
Em Peroaçu, Águeda Cordeiro se desfazia do remorso do falso testemunho enunciado contra o seu tio e a própria irmã, quando tinha ainda 12 anos de idade. Aos 15 e casada com o lavrador Manuel Luís, decidiu confessar que foi coagida pelo padrasto Domingo Ribeiro, de quem sofria maus tratos. O seu depoimento parecia um pedido de ajuda às autoridades eclesiásticas. ${ }^{65}$

E, por fim, na Ilha de Itaparica localizava-se o lavrador de mandioca Paulo Nunes, solteiro, natural da terra, de 43 anos, que há um vivia excomungado por lançar fogo a uma pilha de lenha. Admitiu ter sido negligente por não mandar dois de seus negros confessarem por ocasião da quaresma como mandava a Igreja. ${ }^{6}$

Como se pode notar em todas as ruas e freguesias do recôncavo baiano a visitação do ano de 1618-19 causou impacto na vida dos súditos acirrando brigas antigas, reavivando as culpas e servindo como instrumento de vingança nos jogos de poder. ${ }^{67}$ Se não fosse o desvio e a criação do mecanismo para expiar e punir as culpas, não teríamos registros tão vívidos. Através de depoimentos mais ou menos sinceros, receosos ou vingativos embarcamos em um roteiro elaborado pelos próprios habitantes da Bahia.

\section{Considerações finais}

Muitos pesquisadores consideram as fontes inquisitoriais o retrato vivo da sociedade colonial, permitindo a observação de aspectos sociais, políticos e econômicos. Para a outrora chamada história cultural é matéria prima para compreender o imaginário popular. Do ponto de vista econômico, permite conhecer como os agentes ganhavam a vida. Da história social, apresenta as genealogias, os matrimônios, a parentela, os agregados, os vínculos de senhorio, a escravaria etc.

Buscamos aqui, porém, inserir o espaço no tempo e nas narrativas sobre a cidade, a fim de demonstrar leituras possíveis dos registros inquisitoriais, combinados a relatos de cronistas e à cartografia. A cartografia social torna-se inevitável. Como não imaginar a famosa "rua direita" ou a "estrada que vai para a fonte do lavadeiro" repleta de vida de carne e osso?

\footnotetext{
${ }^{65}$ Idem;

${ }^{66}$ Idem;

${ }^{67}$ NOVINSKY, Anita. “A Inquisição na Bahia: um relatório de 1632 ”. Revista de História 36, n 74 (1 de julho de 1968): 417. Também em: SILVA, Dayane Augusta. "Em tempos de visitas: Inquisição, circulação e oralidade escrava na Bahia (1590-1620)”. Dissertação, UnB - Universidade de Brasília, 2014.
} 
Contudo, os desafios metodológicos dessa tarefa podem frustrar os que buscam a precisão nas visualizações. A precisão escapa até mesmo aos sujeitos históricos que em certos casos emitem informações por aproximação, como a idade ou a própria localização, "no beco que vai para a horta" ou "na estrada que vai para Rio Vermelho" etc. As descrições ganham mais detalhes e atributos à medida que os atores narram episódios da sua circulação e do seu cotidiano. Assim, descobrimos que a Rua Direita era grande, a praça da Câmara pequena, que a procissão seguia pela rua da cadeia etc.

Conhecemos a circulação de pessoas, objetos e bens dentro e fora do recôncavo. Esse último dado mostra a integração do espaço regional à Europa, África e América Hispana. Como no depoimento de Bernardo de Aguirre, cujos familiares estavam dispersos por diferentes razões, mas mantinham os laços com a Bahia. Na circulação de bens, como uma bíblia em castelhano fabricada em Flandres. E por fim, a circulação de ideias, como a superstição que João Poré aprendeu em Madri com Italianos, por exemplo. Tudo isso indica o dinamismo de uma sociedade cosmopolita inserida por diversos meios no mundo atlântico, e não somente pelo tráfico de escravos.

\section{Referências}

ALBERNAZ, João Teixeira; ATTAYDE, Jeronimo de; SEIXAS Y LOVERA, Francisco de. Taboas geraes de toda a navegação / divididas e emendadas por Dom Ieronimo de Attayde com todos os portos principaes das conquistas de Portugal delineadas por Ioão Teixeira cosmographo de Sua Magestade. Disponível em: <https://lccn.loc. gov/78653638>.

ARAÚJO, Renata Malcher de; CARITA, Helder; ROSSA, Walter. Universo urbanístico português: 1415-1822. Lisboa: Câmara Municipal, 2002. (Comissão Nacional para as Comemorações dos Descobrimentos Portugueses).

BRAUN, Georg; HOGENBERG, Franz; BRACHEL, P. von; et al. Civitates orbis terrarum. Civitates orbis terrarvm. 1612-1618. Disponível em: <https://lccn.loc. gov/2008627031>.

CABRAL, Jéssika de Souza. Viver entre o mar e a terra: uma comparação do perfil social e econômico dos perseguidos pelo Tribunal da Inquisição em Salvador e Cartagena das Índias XVI-XVII. In: LUAN VINICIUS BERNARDELLI (Org.). A

Economia numa Perspectiva Interdisciplinar. 1. ed. [s.l.]: Atena Editora, 2019, p. 395-414. Disponível em: <https://www.atenaeditora.com.br/arquivos/ebooks/aeconomia-numa-perspectiva-interdisciplinar>. Acesso em: 11 maio 2020. 
CARDIM, Fernão. Narrativa epistolar de uma viagem e missão jesu... Disponível em: <http://objdigital.bn.br/objdigital2/acervo_digital/div_obrasraras/or58706/ or58706.html\#page/9/mode/1up>. Acesso em: 5 maio 2020.

COSTA, Nátane Oliveira; GORAYED, Adryane; PAULINO, Pedro Ricardo Oliveira; et al. Cartografia social uma ferramenta para a construção do conhecimento territorial: reflexões teóricas acerca das possibilidades de desenvolvimento do mapeamento participativo em pesquisas qualitativas. Ed. Esp. V CBEAGT, p. 73-86, 2016.

FILHO, Nestor Goulart Reis. Lote urbano e arquitetura no Brasil. In: Quadro da arquitetura no Brasil. 9. ed. São Paulo: Editora Perspectiva, 2000, p. 21-53.

HERNÁNDEZ, Luis Alberto Anaya. Las relaciones de los judeoconversos portugueses de Holanda con los de Canarias y América a través de su correspondencia. Anuario americanista europeo, n. №. 4-5, p. 239-258, 2006.

HOLANDA, Sérgio Buarque de. Raízes do Brasil. 7. impr. São Paulo: Companhia das Letras, 1999.

LAET, Joannes de. Beschrijvinghe van West-Indien /. Tweede druck : / in ontallijcke plaetsen verbetert, vermeerdert, met eenige nieuwe caerten, beelden van verscheyden dieren ende planten verciert. Tot Leyden : bij de Elzeviers, 1630. Disponível em: <https://www.biodiversitylibrary.org/bibliography/159247>.

LEAL, Fernando Machado. Catedral Basílica de São Salvador da Bahia: 1657. Cathedral Basilica of São Salvador da Bahia. 2a ed. [s.1.]: Salvador: IPAC, Instituto do Patrimônio Artístico e Cultural da Bahia, 2002.

MARANHO. Retratos da colonização: Os mapas dos Teixeira Albernáz e a construção dos sentidos da América portuguesa seiscentista. In: São Paulo: [s.n.], 2010.

MARQUES, Guida. "Por ser cabeça do Estado do Brasil". As representações da cidade da Bahia no século XVII. In: SOUZA, Evergton Sales; SILVA, Hugo Ribeiro da (Orgs.). Salvador da Bahia: retratos de uma cidade atlântica. Salvador : Lisboa: EDUFBA ; CHAM, 2016, p. 17-43. (Coleção Atlântica).

MENEZES, Paulo Márcio Leal. Atlas Praguense de João Teixeira Albernaz I comparações comentadas de alguns de seus mapas. CARTOGRAFIA HISTÓRICA - TOMO II, v. v. 20 n. 2, 2011. (Museu de História Natural e Jardim Botânico, Universidade Federal de Minas Gerais). 
MOTT, Luiz. Cotidiano e vivência religiosa: entre a capela e o calundu. In: NOVAIS, Fernando (Org.). História da vida privada no Brasil: cotidiano e vida privada na América Portuguesa. São Paulo: Companhia das Letras, 1997, p. 155-200.

NOVINSKY, Anita. A Inquisição na Bahia: um relatório de 1632. Revista de História, v. 36, n. 74, p. 417, 1968.

PESSOA, Ângelo Emílio da Silva. As ruínas da tradição: A casa da Torre de Garcia d'Ávila - família e propriedade no nordeste colonial. USP - Universidade de São Paulo, São Paulo, SP, 2003.

REIS, João José. Domingos Sodré, um sacerdote africano: escravidão, liberdade e candomblé na Bahia do século XIX. São Paulo, SP: Companhia das Letras, 2008.

SCHILDER, G. The Netherland Nautical Cartography from 1550 to 1650. [s.1.]: Instituto de Investigação Científica Tropical, 1984. (Centro de Estudos de História e de Cartografia Antiga Lisboa: Série separatas). Disponível em: <https://books. google.com.br/books?id=Lfsw3SW3RcoC>.

SCHURMANN, Betina. Urbanização colonial na América Latina: cidade planejada versus desleixo e caos. Textos de História, v. 7, n. 1/2, p. 149-178, 1999.

SILVA, Dayane Augusta. Em tempos de visitas: Inquisição, circulação e oralidade escrava na Bahia (1590-1620). Dissertação, UnB - Universidade de Brasília, Brasília, 2014.

SOUZA, Laura de Mello e. 0 diabo e a Terra de Santa Cruz: feitiçaria e religiosidade popular no Brasil colonial. São Paulo: Companhia das Letras, 1986.

SOUZA, Gabriel Soares. Tratado descriptivo do Brasil em 1587. 2 ed. Rio de Janeiro: Typographia de João Ignacio da Silva, 1879. Disponível em: <http://www2. senado.leg.br/bdsf/handle/id/242787>.

VAINFAS, Ronaldo (Org.). Confissões da Bahia. [s.1.]: Companhia das Letras, 1997.

VAINFAS, Ronaldo. Trópico dos pecados: moral, sexualidade e Inquisição no Brasil. Rio de Janeiro: Civilização Brasileira, 2010.

Livro 20 das denunciações que se fizeram na visitação do Santo Ofício na cidade do Salvador da Baía de Todos os Santos, do Estado do Brasil. - Arquivo Nacional da Torre do Tombo - DigitArq. Disponível em: <https://digitarq.arquivos. pt/details?id=2318687>. Acesso em: 7 maio 2020. 368 f. (69 f. em branco); papel, capa em perg. 
Livro das confissões e reconciliações que se fizeram na visitação do Santo ofício na cidade do Salvador da Baía de Todos os Santos, do Estado do Brasil. Arquivo Nacional da Torre do Tombo - DigitArq. Disponível em: <https://digitarq. arquivos.pt/details?id=3969860>. Acesso em: 7 maio 2020. 214 f. (66 f. em branco); papel, capa de pergaminho.

Artigo recebido para publicação em 20/05/2020 Artigo aprovado para publicação em 03/12/2020 